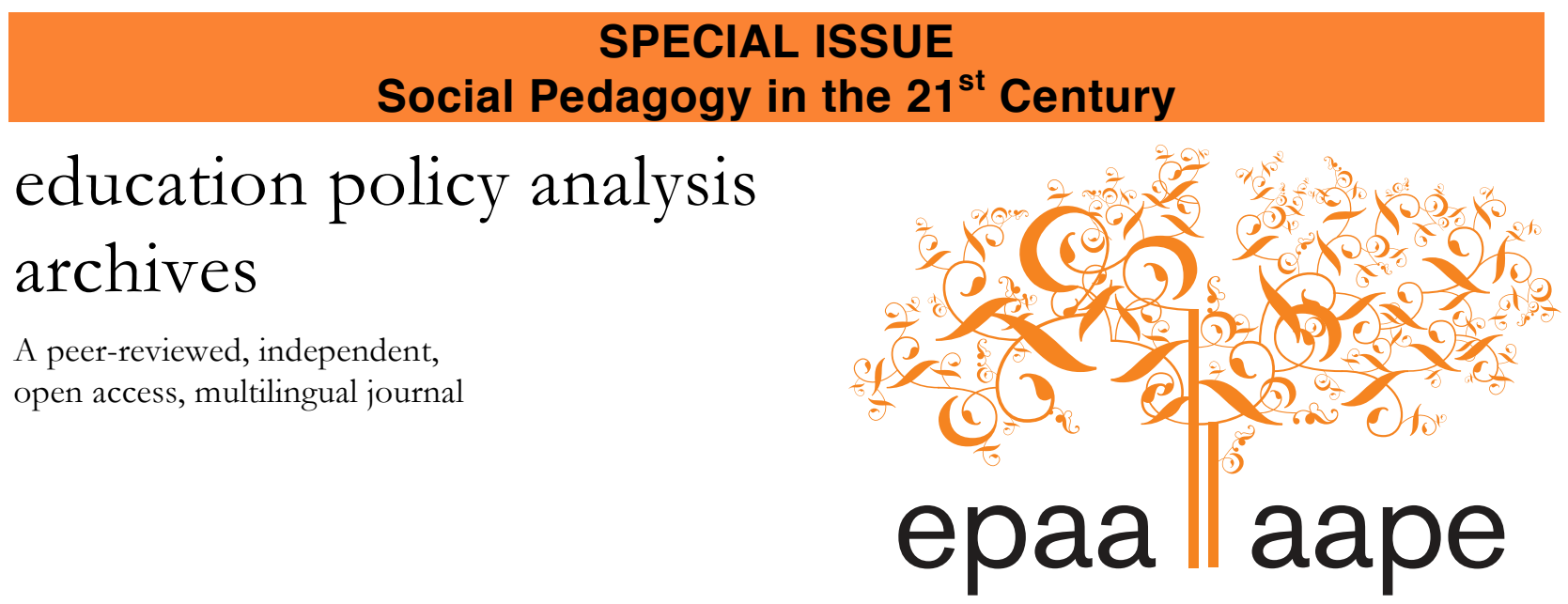

Arizona State University

Volume 21 Number $43 \quad$ April 30 ${ }^{\text {th }}, 2013 \quad$ ISSN 1068-2341

\title{
Social pedagogy in modern times
}

\author{
Niels Rosendal Jensen \\ Aarhus University \\ Denmark
}

Citation: Rosendal Jensen, N. (2013). Social pedagogy in modern times. Education Policy Analysis Archives, 21(43). Retrieved [date], from http://epaa.asu.edu/ojs/article/view/1217. This article is part of EPAA/AAPE's Special Issue on Social Pedagogy in the 21st Century, Guest Co-Edited by Dr. Daniel Schugurensky and Michael Silver.

Abstract: The article identifies several key concepts used to describe and categorize social pedagogy. The first section of the paper establishes a framework for considering the diversity that characterizes the field, including reflection on social pedagogy's theoretical, political and social dimensions. This is followed by a discussion based on a holistic understanding of the interaction between individuals and society, which leads to recognition of the profession's tendency to present itself with a "Janus face." The paper concludes by pointing out prospects for further development of social pedagogy in the dialectic between theory/research and pedagogical practice.

Keywords: Social pedagogy; theoretical approaches; profession.

\section{Pedagogía social en tiempos modernos}

Resumen: Este artículo identifica algunos conceptos claves que se utilizan para describir y categorizar la pedagogía social. La primera parte presenta un marco conceptual para considerar la diversidad que caracteriza a este campo, incluyendo una reflexión sobre las dimensiones teóricas, políticas y sociales. A continuación se presenta una discusión basada en una comprensión holística de la interacción de los individuos con la sociedad, lo que conduce al reconocimiento de la tendencia de la profesión por presentarse con la doble cara de Jano. El artículo concluye señalando las perspectivas de desarrollo de la pedagogía social en la dialéctica teoría-investigación y en la práctica pedagógica. 
Palabras-clave: pedagogía social; perspectivas teóricas; profesión.

\section{Pedagogia social nos tempos modernos}

Resumo: Este artigo identifica alguns conceitos-chave que são usados para descrever e classificar a pedagogia social. A primeira parte apresenta uma estrutura conceitual considerando a diversidade que caracteriza esta área, incluindo uma reflexão sobre as dimensões teóricas, políticas e sociais. A continuação é uma discussão baseada em uma compreensão holística da interação dos indivíduos com a sociedade, o que leva ao reconhecimento da tendência da profissão para aparecer com a dupla face do Jano. $\mathrm{O}$ artigo conclui observando as perspectivas de desenvolvimento da pedagogia social entre a dialética da teoria e pesquisa e em a pratica pedagógica.

Palavras-chave: pedagogia social, perspectivas teóricas; profissão.

\section{Introduction}

At the European level, social pedagogy is highly relevant, and yet it seems to be "an important but widely misunderstood member of the social professions" (Lorenz, 2008, p. 625). The way in which social pedagogy has been defined by both practitioners and academics has been to conceive of it as a 'blurred notion'. One of the main reasons why social pedagogy is conceptualized in a plethora of definitions stems from the multiplicity of dimensions confounding its definition.

This article attempts to make sense of a complex concept. Modern social pedagogy deals with a complicated field of divergent perspectives and interests that sometimes are contradictory. In the first part, this article presents three perspectives of social pedagogy that are partly focused on national differences. They encompass theoretical, political and social dimensions, and suggest that 'unity in diversity' is a preferable approach for social pedagogy instead of insisting on producing a common paradigm. The second part deals with social pedagogy as a profession, and particularly with the need for professionalization. This part also describes some confusion due to changes of institutions and organizations, professional competences, and legislation, then concludes with six tasks for social pedagogy. Finally, the conclusion summarizes the article's main argument and suggests additional perspectives.

\section{The theoretical dimension}

In exploring social pedagogy as a theory, three main approaches can be identified. The first approach refers to social pedagogy as an established academic discipline: From this perspective, social pedagogy is a social science because of its eye for the social life or living conditions and also a reality science because it is based on empirical facts. In addition, it is an action science because it is oriented towards influence and change of both people and structures and last but not least, it is an interdisciplinary science because it relates its own theories to the realizations of reference disciplines without binding to single sciences (Mühlum, 2000, p. 99, my translation). This approach is based on two assumptions. Firstly, that we are dealing with an independent empirical covered knowledge field. Secondly, that social pedagogy is an integration of many basic sciences. These two assumptions provide the germ of a modern social pedagogy.

The second approach emphasizes the particular characteristic of social pedagogy. From this perspective, social pedagogy is a special way of thinking, not a particular method or particular style of work. Social pedagogy integrates elements of science, education and work, and as an academic discipline it includes three systems: a scientific system, an education system and a work system (Hämäläinen, 2003, p. 150). 
The third approach places the emphasis on social pedagogy being pedagogy (Rosendal Jensen, 2006, p. 228), but at the same differs from the individual and general pedagogy by maintaining a historical-societal reflection framework: Social pedagogy in its historical-societal development is regarded as societal responses to address the fact that children, adolescents and elderly have trouble mastering the challenges that are a result of social disintegration (Rosendal Jensen, 2006, p. 234-5).

In different ways, the three approaches help us to understand pedagogy as both science and profession and not as a scientific approach to a profession. In addition, they suggest that social pedagogy has three dimensions: it is a complex field being constituted of practical social pedagogical work, it is an educational subject, and it is a field of research. In Denmark, social pedagogy has been traditionally a professional work; the research having arrived more recently. Furthermore, the three elements of the field have their own logic, which can complement or contradict each other. Such logic is even relatively independent of the theories, the parts of the educational subject, and the parts of professional practice with which the orientation complies. One could perhaps be inspired by Rasmussen, Kruse, and Holm (2007), who distinguish between practice knowledge, professional knowledge and research knowledge. By using knowledge forms as markers one realizes that knowledge requirements vary, and thus so too do perceptions of theory.

The existence of these three approaches suggests that a common paradigm is neither possible nor desirable, at least not for the time being. Efforts to impose one and only one perception would merely lead to the creation of more competing paradigms and perhaps a new marginalization. Disagreements should not provoke panic. On the contrary, they can stimulate the ongoing discussion about the understanding of social pedagogy. Social pedagogy constitutes itself subsequent to a number of classic academic disciplines. This can be explained by its purpose, which is to act upon a societal problem field based on specific practical intentions. This aspect also contributes to justify the current status of the discipline.

The fact remains that social pedagogy, like any other science (at a minimum) should include "a subject/research field, a method, a technical language and ideally a core curriculum containing a canon of texts which must be studied" (Niemeyer, 2002, p. 341, my translation). Although this is a desirable situation, it is still far from being a possibility. However, Niemeyer's point is interesting, since it points toward establishing a common basis for conversation. Without such, it makes no sense to argue about different perceptions and approaches. The aim may be to establish unity in diversity by finding a "hard core," which is recognized by all or most (Rosendal Jensen, 2011a, p. 6671). When we use the social pedagogical problem as the starting point for the search process, the integration challenge (in the modern turn) is at the core of the educational scientific debate on social pedagogy and individual pedagogy (Reyer, 2008, p. 45; Rosendal Jensen, 2006). In Reyer's (2008) sharp formulation, social pedagogy forms a unifying theoretical framework for the modernization of teaching.

\section{The political and social dimensions}

Social pedagogy is also about politics. In a historical perspective, social pedagogy goes hand in hand with political initiatives to overcome poverty and improve societal wellbeing. While the political strategy was directed against an external social reform, the pedagogical strategy was targeted at society's internal reform through education (Hämäläinen, 2003, p. 136). To summarize, the academic discipline is inclusive, not exclusive. We must consider its parts to understand what social pedagogy is. This represents a different way of thinking. The alternative would be for each approach to struggle for hegemony and thus cause an internal polarization, which is rightly warned against: As Lorenz (2008) notes, "It is not surprising that the fundamental ambiguity of the term [social pedagogy] involves a risk of polarizing its development" (p. 638, my translation). Basically, in social 
pedagogy we are dealing with a hybrid that can be considered as a science and as a practice in the sense that theory and practice -or thought and action- come together (Úcar, 2011). The polarization tendencies overshadow what, after all, is common. One explanation could be that the social pedagogical problem gets pushed into the background behind the pursuit of an understanding of social pedagogy as an institutional field/practice or education.

The social pedagogical problem "was to make the integration problems that had arisen with the second wave of individualization in the Modernity, pedagogical comprehensible" (Jensen, 2006; Reyer, 2008, p. 45). The first wave can be associated with Karl Marx's(1848/49) understanding of modern society in The Communist Manifesto, where the identity of the wage laborer becomes essential. The second wave was identified 40 years later by Ferdinand Tönnies (1887) in Community and Society, in which describes the loss of the naturally occurring community as a necessary consequence of society's development. Both waves put pressure on pedagogy to merge with the latest developments in other disciplines like economics and sociology. As a result, this is exactly what contemporary social pedagogy endeavored to do. Even today, this is a salient theme, since we live in a digitalized capitalism that continues to cause disintegration (Rosendal Jensen, 2006, p. 101113). Throughout modern history, the problems of integration have returned again and again in new shapes. Stated as a formula, we can say, what is seen as a solution in one historical period appears in a later period as a problem.

\section{Convenience or analysis: social pedagogy as critical potential}

Sometimes, a variety of problems like migration, crime, or divorce, end up being conveniently aggregated under the label of social pedagogical problems. Likewise, sometimes social pedagogical problems are attributed to the individual, without understanding that most often they are caused by societal structures. Moreover, social pedagogy has sometimes been considered a subdivision of general pedagogy and as an education of professionals for a specific professional area.

However, social pedagogy argues that the existing definitions of upbringing and pedagogy are too individualistic. It is untenable to view the connection as a relationship between two people in a vacuum. Processes of upbringing take place in a complex field comprised of many educational institutions, educators, and co-educators (media, internet, etc.). Children and young people are only found in social contexts such as family, school, club or group of peers. A purely dyadic relationship is an unrealistic oversimplification. Social pedagogy also argues that while the institutional dissemination of educational processes is forgotten, the institutional environments determine the form and content of the upbringing processes. Upbringing and socialization practices can only be understood with knowledge of the educational function of the family, the child-care institution, and the school.

Furthermore, social pedagogy draws attention to the role of the social environment in upbringing and socialization. Analyses of the historical situation and social status are necessary because they can explain the development of discipline, power and dependency, which frame the relationships between individualization and structuring of institutions and schools, etc. Using the social pedagogical approach one could also ask why the upbringing and socialization reflect their own origins and development to such a lesser extent. Often we are dealing with definitions that are eternal and lack historical knowledge. The facts are quite the opposite. Upbringing ideals change over time. Thus, the opportunity to strengthen the sight of the historical and social conditions for the upbringing's own possibilities and limitations is missed. The lack of a social pedagogic substantial input also implies that the normative and ethical dimension of educational processes is simplified. It is inadequate to describe the help and support from the more mature for the not yet mature. In most cases struggles are an issue: will children and young people even receive the offered 
help? Should they be forced to (as they are in several contexts), and what does this symbolic or physical violence mean for the relationship between educators and the youth they educate? Social pedagogy plays a critical role, but this role takes a variety of forms that are linked to different historical traditions.

\section{"The whole person"}

Eriksson \& Markström (2003, 2000) have identified three different tracks in social pedagogy. First and foremost is the continental tradition, which draws on Natorp's ideas related to the German labor movement and has a collective orientation. Subsequently, they draw their attention to the American tradition that has roots in philanthropy, (with Mary Richmond as an example), and have a therapeutic and individual orientation. The third is a pedagogical orientation, inspired by the ideas of Dewey and Freire. For Dewey, education can make a significant contribution to the development of democracy (he seems to agree with Natorp in this). Freire stresses that dialogue, awareness raising, emancipation, and reflective action are essential elements to transform reality. The social pedagogue plays a vital role as facilitator of local initiatives in active collaboration with voluntary organizations. On the one hand this shows the strength of social pedagogy, but also its weakness, as emancipation is no issue, if the target alone is rehabilitation and integration. Thus, we can identify three main streams: adaptation-oriented, mobilization and pedagogical (Eriksson \& Markström, 2003, 2000). One could add a fourth independent tradition, namely the group's role in youth work (Makarenko, 1955; Rasmussen, 1983). These combine to create a recurring theme in social pedagogy, namely that of "the whole person". Indeed, the idea of the whole person is central to social pedagogy theory and practice (Connelly \& Milligan 2012, p. 98-99).

Different interpretations exist based on different concepts of humanity, society, view of history, scientific school, morality, political beliefs, and ideological movements. Some authors see this as a reflection of a particular approach to self and to society. Since Pestalozzi (1746-1827), a feature of social pedagogy has been the tendency to understand human as a whole. Pestalozzi is considered the originator of this perspective, which includes three elements: head, heart and hands, not to be understood as three parts of the human body, but as three angles of a single person. This implies for one that any social pedagogical effort will require an approach that integrates the intellectual, moral and practical education. The personal autonomy, which is a central aim of any pedagogy or education, is the result of an integration that is not achieved by using fragmented efforts. The point is that the idea of "the whole person" appeals to research as well as to professional work, and ties the two logics together. Just as there is a certain Babylonian confusion about understanding what theoretical social pedagogy is, there is confusion when one speaks of pedagogical efforts. According to custom one is referring to care, help, support, supervision, treatment, mobilization and education. Again, we find different interpretations of what those concepts cover. Pestalozzi was the first to link help and education together (Horlacher, 2007).

According to the social pedagogy tradition, Natorp found the mobilizing aspect of the labor movement as incarnation of the idea of community. Since work is the basis for the human identity formation, and it also could lead to liberation and societal democratization, Natorp imagined that work had to be released from alienation (i.e. capitalism) and instead serve human emancipation. The pedagogical task was not to interfere in this liberation struggle, but rather to provide new educational conditions to support the liberation. Thus, teaching was charged with translating the challenges of industrial capitalism to a liberation perspective. In Natorp's time, this project failed; diverted by Hitler's National Socialism and millennial Reich. In that particular historical moment, social pedagogues indulged state orders. 


\section{The Janus face of the profession}

Social pedagogues are considered to be experts whose knowledge and skills have universal extent. At least three traditions regarding how professionalism is to be understood can be identified. The first one emphasizes universal professional skills and methods. The focus is the relation between the social pedagogue and user/citizen based on individual interpretations of the user's situation. The second one, called the 'competence based qualification', is a management-oriented understanding that emphasizes specific tasks and core competencies. The third one regards the social pedagogue as a reflective or reflexive professional. This involves a critical review of social pedagogy in order to maintain alternate and flexible models of action. Reflexivity becomes particularly decisive when knowledge and skills are multifaceted (formal, non-formal, informal and tacit), uncertain and contextual. The idea of reflective or reflexive professionals is probably more future-oriented than the other two.

Based on prior research, four perspectives on professionalism seem especially important: implementation, institution, profession and citizenship/democracy (Müller, 2007; Rosendal Jensen, 2011a, p. 78-83). I do not have space to pursue this further on this occasion. Instead, my focus in this section of the paper is on the duality of the profession. Institutional contexts like schools and daycares are value-laden and aim at transmitting values, norms and social roles. The professionals observe and categorize their "costumers" by using cognitive schemata derived from other disciplines (e.g. psychology). Further pedagogical practice is supported by the institutional culture and the professional ideology, overestimating the importance of the outcomes of a given action or intervention. This is reflected by attitudes and points of view such as "to meet the user where he needs to be met", "see the user as a whole person", and the like. This culture is brought into the institution, which also may contain special norms, values and beliefs - an ideological preparedness formulated in a positive way (Nygren, 2004), but an ideological backlog as well. Moreover, the pedagogical work is romanticized e.g. by stressing out the value of employees in relational pedagogy (Egelund et al., 2010; Jensen, 2009). This will cause a gap between the professional's assumption of what she is expected to do and what she actually does. This may explain why many things in social pedagogical work are explained with airy terms such as 'relationship', 'person', 'moment', etc. It may be called professional degeneration; if one gives up trying to find explanations as to what it is exactly that works for whom, where and how.

The argument is also found in relation to discussions of intervention not being able to be planned - unless one is caught up in the illusion that pedagogical actions can be controlled. Does this idea stand when it comes down to it? We have the remarkable experience in common, that we have succeeded in affecting human behavior in ways that were both planned and predictable based on targeted effort and sufficient power. The fact that plans sometimes turn out differently or result in surprising consequences does not mean that the alternative is to settle for rules of thumb, prescriptions or manuals.

Having drawn attention to the less flattering side of the profession, we must also consider its more constructive attributes. Despite perceptions that the field lacks organization, professionals make use of terms such as "intuition", "experience", "pragmatism" and "scientific rationalism", and combine them in a kind of scientific curiosity (Bhaskar, 1975; Bunge, 1999, 1998, 1996). They are of course subject to restrictions and may also restrict themselves in their actions. The "normalization" of social pedagogy can lead to some limitations. While in the 1960s and 1970s social pedagogy was perceived as 'dangerous' because it was characterized by political struggle against inequality and undignified treatment of vulnerable citizens, such as the disabled, today social pedagogy is close to finding a 'normal' reproductive practice, i.e. like all other welfare professionals that only provide 
services and help reproduce the system. This harsh point is included in order to show that a change has taken place - the profession has realized that the welfare state no longer exists as in the good old days. On one hand a professionalization takes place "from above" and it is based on a perpetual comprehensive legislation. The ideal in this context is a "professional specialist" operating on the basis of a "skilled profession" and by virtue of his "educational credentials" (in the sense of a monopoly on a specific segment of the professional labor market)) working in good faith in the machinery of the bureaucracy of the welfare state (Weber, 1972 [1922], p. 76ff.). In brief, this means a professionally trained person who thinks solely in terms of social services. At the same time, in addition to the understanding of being street level bureaucrats, social pedagogues have to maintain their indignation outrage of injustice, and commitment to social justice. This leads to a fundamental question: does the limited framework of the professional occupation work on science, and may science also add something to the profession?

Overall, we can identify a dual movement "from above" and "from below" with a preliminary apparent preponderance of orders from above. Has this dynamic also taken the life of the dynamic and critical social pedagogy? Not necessarily. The social pedagogue as a "professional specialist" does not live in a different world from the social pedagogue as a critical thinking person. This is not a matter of parallel lines never to intersect but rather of overlapping lines. For instance, in the same residential day-care institution several social processes take place simultaneously, which alternately appeal to the professional specialist and the critic. This implies that the normalization does not necessarily separate the critical element. It is not necessarily a question of a hierarchical relationship in which the law prevails over critical decisions. It is rather a question of a relational environment because institutional practices are not a foregone conclusion, but rather a (re)production of social practices. Each institution is marked by uneven and sometimes conflicting historical and societal developments, cultural imprints and political decisions, which all together form a relatively stable social pattern of action.

The normalization is also important for the development of social pedagogy as a science that can be summarized in terms of three perspectives on the relationship between discipline and profession, namely (1) science and education policy, (2) institutions (colleges and universities) and (3) professional policy (Rosendal Jensen, 2011b, p. 29-30). Thus, it is essential to support and legitimize the professional autonomy of the social pedagogy practitioners based on an autonomous scientific discipline whose task is to educate, engage in empirical research and develop theories. In the field of institutional and organizational practices, this means to argue for social pedagogical institutions, chairs and disciplines.

With this disciplinary autonomy, a reorganization of institutional structures at universities and colleges has been identified, which aims to ensure the professional counterpart of the scientific discipline, i.e. social pedagogical practices, improved opportunities for reflection and further development of professional practice. For the profession, this implies that the knowledge of the professional work goes far beyond the profession's own ranks. Furthermore, it will be possible to gain insights into the effects of professional interventions and organizational structures. Finally, the professional standards may also be included in the educational programs so that professionals will be educated primarily by teachers who have knowledge of and insight into their profession.

This would involve some "great leap forward" that includes six tasks:

- an empirical justification of knowledge about the research subject, including definitions of key disciplinary concepts (theoretical development and empirical based research)

- a further clarification of social pedagogy's function

- the development of customized research tools 
- an evaluation of the organizational structures as well as the professional forms of organization of work

- an evaluation of current professional intervention practices

- the formulation of new concepts of and to use for practice at both intervention and organizational levels.

However, one may probably realize that this turns into a balancing act. On the one hand, social pedagogy as an academic discipline must display suitable proximity to the practice field, while it must maintain a certain amount of independence. The discipline must serve both the intra- and interdisciplinary communication and also between discipline and profession.

My optimism may be perceived as too idealistic for some readers, but my perspective is based on the premise that the discipline may contribute to serve as inspiration to the professional work in five different ways:

- Professionals' communication and collaboration. The theoretical and empirical output may provide a semantically consistent basis better adapted to the problem, thereby contributing to a more focused profession-oriented discussion in professional practice;

- Results for the professional acting. A more obvious distinction between profession internal understanding on the basis of a technical language and understanding users plus knowledge transfer available for users based on everyday language, may increase efficiency in the interventions while maintaining the autonomy of users' everyday lives;

- Professional knowledge and technology transfer. The link between discipline internal and adapted discipline external knowledge and procedure stores in practice may be an important factor for innovative developments in the profession itself, but also in social innovations;

- Sociopolitical act. An overall aim will be to strengthen the profession, including its social recognition, which in turn implies a recognition of those tasks that the profession is set to handle;

- Inter-professional competitiveness. Social pedagogy as an established discipline will strengthen social pedagogy in competition with other person oriented welfare professions.

\section{Summary and conclusions}

This article aimed at presenting a number of challenges for social pedagogy as a paradigm for research and for professional practice. We cannot promote a "one size fits all" approach, but we can point to the need of a continued discussion. This is not a merely academic challenge. Moreover, it has to be solved by a closer cooperation. In addition, calls for a unified paradigm were rejected due to divergent perspectives, theoretical frameworks and ways of organizing social pedagogical interventions. Though there may be wishful thinking of establishing a common paradigm, this paper points to accepting a certain divergence with respect to different traditions and path dependencies. When analyzing implications for practice, two additional problems emerge. First, there seem to be strong disagreements between practitioners and academics about valuable research, and this is a serious obstacle to the scientific growth of the field. I recommend a closer cooperation to overcome the impression of social pedagogy as a fragmented practice. Second, the conditions of implementation are shifting rapidly due to the division of labor, changes of the labor market and new challenges to education and training. However, it is still necessary to offer perspectives to go beyond national and local constraints by adopting an international perspective in an attempt to 
liberate the profession and the research from their traditional national identities. Indeed, while respecting national differences, a new internationalism is needed.

Internationalization, globalization as well as Europeanization place distinctive framework conditions for social pedagogical work. As Askeland and Payne note, social work "has become a part of the global market in that those who have the resources to produce and market social work literature are able to disseminate their theoretical views and skills ...throughout the world as the way of handling social issues in a professional way, ignoring the different local context in which it is produced and in which it should be read" (Askeland \& Payne, 2006. p. 734). If the challenge to the classic welfare state further lies in the concept of "the competitive state", these are new terms to work professionally with. Today, it is the political conditions for the supply of goods, services and work that tends to be managed. Thus, new problems "originating from non-utilization of labor, capital and other productive factors" are identified (Pedersen, 2011, p. 51). The active welfare state intends to reform the existing welfare state in order to adjust the labor force for utilization on the labor market to ensure that the individual is capable of constantly adapting himself or herself to labor market requirements. These policies are aimed at employability, that is, the individual's ability to find employment, and approach that emphasizes personal responsibility. Researchers in several European countries have raised concerns about the seriousness of this situation (see, for instance, Garrett, 2009; Reutlinger, Baghdadi, \& Kniffki, 2011; Rogowski, 2010; Schweppe \& Sting, 2006). In these works researchers relate to the macro-, meso- and micro level as well as economic, social, political and cultural issues. They analyze a number of old acquaintances like migration, poverty, social justice, exclusion, culture/education, school-work transitions, health and housing, in light of the social and educational policies that are caused by -and in turn influence- societal changes. In a full circle, this brings us back to the issue of social pedagogy as a decisive factor.

\section{References}

Askeland, G.A. \& Payne, M. (2006). Social work education's cultural hegemony. International Social Work, 49(6), 731-43

Bhaskar, R. (1975). A Realist Theory of Science. Sussex: The Harvester Press

Bunge, M. (1996). Finding Philosophy in Social Science. New Haven/London

Bunge, M. (1998). Philosophy of Science. From Problem to Theory. Vol. 1. New Brunswick/London;

Bunge, M. (1999). The Sociology-Philosophy Connection. New Brunswick/London:

Connelly, G. \& Ian Milligam (2012). Residential Child Care. Series Policy and Practice in Health and Social Care. Edinburgh: Dunedin Academic Press Ltd.

Durkheim, É. (1975 [1911]). Opdragelse, uddannelse og sociologi. København: Carit Andersen.

Egelund, T., Jacobsen, T.B., Hammen, I., Olsson, M., \& Høst, A. (2010). Sammenbrud i anbringelser af unge: Erfaringer, forklaringer og årsagerne bag. København: SFI - Det nationale Forskningscenter for Velfærd.

Eriksson, L. \& Markström, A-M. (2000). Den svårfangede socialpedagogiken. Lund: Studentliteratur.

Eriksson, L. \& Markström, A-M. (2003). Interpreting the concept of social pedagogy. In A. Gustavsson, H-E., Hermansson, \& J. Hämäläinen (Eds.), Perspectives and Theory in Social Pedagogy (s. 9-23). Göteborg: Daidalos.

Fuller, R. C. \& Myers, R. (1941). Some Aspects of a Theory of a Social Problem. American Sociological Review, 6, 24-32.

Garrett, P.M. (2009). 'Transforming' children's services: Social work, neoliberalism and the 'modern' world. Maldenhead: Open University Press - McCraw-Hill Education. 
Horlacher, R. (2007). Die Rolle Pestalozzis in der Konstituerung der Sozialpädagogik als wissenschaftliche Disziplin in der modernen Gesellschaft. Wíesbaden: VS Verlag für Sozialwissenschaften, s. 159-173.In: Dollinger, B., Carsten Müller \& Wolfgang Schröer (Hrsg.). Die sozialpädagogische Erziehung des Bürgers: Entwürfe zur Konstitution der modernen Gesellschaft, s. 159-173.

Hämäläinen, J. (2003). Developing social pedagogy as an academic discipline, in: Gustavsson, A., Hermansson, H-E., Hämäläïnen, J. (eds). (2003). Perspectives and Theory in Social Pedagogy. Göteborg: Daidalos, s. 133-153,

Lorenz, W. (2008). Paradigms and politics: Understanding methods paradigms in an historical context: The case of social pedagogy. British Journal of Social Work, 38, 625-644.

Makarenko, A.M. (1955). Vejen til livet: En fortalling om opdragelse. København: Forlaget MEGA

Mühlum, A. (2000). Sozialarbeitswissenschaft: Profil - Programm - Provokation. In Pfaffenberger, H., Scherr. A., Sorg, R. (Eds.). Von der Wissenschaft des Sozialwesens (s.84-106). Rostock: Neuer Hochschulschriftenverlag, Dr. Ingo Koch \& Co KG.

Müller, C. (2007). Keine Demokratie ohne Bürger?! In Dollinger, B., Müller, C. \& Schröer, W. (Hrsg.). Die sozialpädagogische Erziehung des Bürgers: Entwürfe zur Konstitution der modernen Gesellschaft (s. 13-28).

Niemeyer, C. (2002). Sozialpädagogik - ein Weckruf. neue praxis, 4(02), 321-345.

Nygren, P. (2004). Handlingskompetanse: Om profesjonelle personer. Oslo: Gyldendal Norsk Forlag AS.

Pedersen, O.K. (2011). Konkurrencestaten. København: Hans Reitzels Forlag

Pongratz, L. A. (2010). Sackgassen der Bildung: Pädagogik anders denken. Paderborn: Verlag Ferdinand Schöningh GmbH \& Co. KG.

Rasmussen, H. (1983). Gruppeopdragelse. Serien Marxistisk pædagogik og psykologi 6. København: Forlaget Tiden.

Rasmussen, H. (1984). Socialpædagogik: Opdragelse på institution. Serien Socialpædagogisk Bibliotek. København: Munksgaard.

Rasmussen, J., Kruse, S. \& Holm, C. (2007). Viden om uddannelse: Uddannelsesforskning, pædagogik og pædagogisk praksis. København: Hans Reitzels Forlag.

Reutlinger, C., Baghdadi, N., \& Kniffki, J. (2011). Die soziale Welt quer denken. Tranmsnationalisierung un ibre Folgen für die Soziale Arbeit. Berlin: Frank \& Timme. Verlag für wissenschaftliche Literatur.

Reyer, J. (2008). Socialpædagogikkens teoritab: en historie om forfald eller om forandring. Tidsskrift for Socialpadagogik, 22(2008), 44-59.

Rogowski, S. (2010). Social work: The rise and fall of a profession? Bristol: The Policy Press.

Rosendal Jensen, N. (2005). Uddannelsessociologien i nyt lys? En gammel kending revisited. In Inger M. Bryderup (red.). Social ulighed - et festskrift i anledning af professor Erik Jorgen Hansens 70 års fodselsdag. Kobenhavn: Danmarks Padagogiske Universitets Forlag (s. 61-82).

Rosendal Jensen, N. (2006). Grundbog i socialpadagogik. Viborg: Forlaget PUC, CVU-Midtvest

Rosendal Jensen, N. (2009). Handlekompetence $i$ socialpadagogisk praksis på dogninstitutioner. København: www.dpu.dk/hpa/publikationer

Rosendal Jensen, N. (2011a). Danish social pedagogy as a model for Europe? In J. Kornbeck \& N. Rosendal Jensen (Eds.) (2011), Social Pedagogy for the Entire Lifespan, Volume I (pp. 66-87). Bremen: Europäischer Hochschulverlag.

Rosendal Jensen, N. (2011b). Socialpædagogik som videnskab udgør grundlaget for uddannelsen af socialpædagoger, in Tidsskrift for Socialpadagogik, 14(2), 24-31.

Schweppe, C., \& Sting, S. (Hrsg.). (2006). Sozialpädagogik im Übergang: Neue Herausforderungen für Disziplin, Profession und Ausbildung. Weinheim und München: Juventa Verlag. 
Úcar, X. (2011). Social Pedagogy: Beyond Disciplinary Traditions and Cultural Contexts? In J. Kornbeck \& N. Rosendal Jensen (Eds.) (2011), Social Pedagogy for the Entire Lifespan, Volume I (pp. 124-153). Bremen: Europäischer Hochschulverlag.

Weber, M. (1972 [1922] 5. Auflage). Wirtschaft und Gesellschaft: Grundriss der verstehenden Soziologie. Tübingen: Mohr. 


\section{About the Author}

Author Niels Rosendal Jensen

Department of Education, Aarhus University, Denmark

Affiliation information

Email: ealicias@mla.nsclub.net,nrj@dpu.dk

Niels Rosendal Jensen is Associate Professor at Aarhus University where his appointment is in the research program of social pedagogy and the Master program of sociology of education. He was Head of Department 2005-2008 and is now doing research on a regional, national and European level funded by Danish regions, the Danish Parliament and the EU Commission. He has published a number of books on social pedagogy: The Diversity of Social Pedagogy in Europe (EHV 2009), Social Pedagogy for the Entire Lifespan, Vol. I \& II (EHV 2011 \& 2012).

\section{About the Guest Co-Editors}

Daniel Schugurensky

Arizona State University

Email: dschugur@asu.edu

Daniel Schugurensky is Full professor at Arizona State University, where he has joint appointment in the School of Public Affairs and the School of Social Transformation. He is the Head of the Area of Justice and Social Inquiry, and the coordinator of the Master's program in social and cultural pedagogy. He has written extensively on youth and adult education, community development and participatory democracy. Among his recent authored and coedited books are Ruptures, continuities and re-learning: The political participation of Latin Americans in Canada (Transformative Learning Centre, University of Toronto, 2006), Four in Ten: Spanish-Speaking Youth and Early School Leaving in Toronto (LARED, 2009), Learning citizenship by practicing democracy: international initiatives and perspectives (Cambridge Scholarly Press, 2010), Paulo Freire (Continuum, 2011), and Volunteer work, informal learning and social action (Sense 2013).

Michael Silver

Arizona State University

Email: Michael.Silver@asu.edu

Michael Silver is a Research Fellow at the National Center on Education and the Economy and the Center for the Future of Arizona. As a Doctoral Student in Educational Policy and Evaluation, his research focuses on policies affecting educational equity and issues of social justice - particularly those related to historically vulnerable, minority populations. 


\section{SPECIAL ISSUE \\ Social Pedagogy in the $21^{\text {st }}$ Century education policy analysis archives}

Volume 21 Number 43

April 30 $0^{\text {th }}, 2013$

ISSN 1068-2341

\section{@}

SOMERIGHISRESERVED Readers are free to copy, display, and distribute this article, as long as the work is attributed to the author(s) and Education Policy Analysis Archives, it is distributed for noncommercial purposes only, and no alteration or transformation is made in the work. More details of this Creative Commons license are available at http://creativecommons.org/licenses/by-nc-sa/3.0/. All other uses must be approved by the author(s) or EPAA. EPAA is published by the Mary Lou Fulton Institute and Graduate School of Education at Arizona State University Articles are indexed in CIRC (Clasificación Integrada de Revistas Científicas, Spain), DIALNET (Spain), Directory of Open Access Journals, EBSCO Education Research Complete, ERIC, Education Full Text (H.W. Wilson), QUALIS A2 (Brazil), SCImago Journal Rank; SCOPUS, SOCOLAR (China).

Please contribute commentaries at http://epaa.info/wordpress/ and send errata notes to Gustavo E. Fischman fischman@asu.edu

Join EPAA's Facebook community at https://www.facebook.com/EPAAAAPE and Twitter feed@epaa_aape. 


\title{
education policy analysis archives editorial board
}

\begin{abstract}
Editor Gustavo E. Fischman (Arizona State University)
Associate Editors: David R. Garcia (Arizona State University), Stephen Lawton (Arizona State University)
\end{abstract}

Rick Mintrop, (University of California, Berkeley) Jeanne M. Powers (Arizona State University)

Jessica Allen University of Colorado, Boulder

Gary Anderson New York University

Michael W. Apple University of Wisconsin, Madison

Angela Arzubiaga Arizona State University

David C. Berliner Arizona State University

Robert Bickel Marshall University

Henry Braun Boston College

Eric Camburn University of Wisconsin, Madison

Wendy C. Chi* University of Colorado, Boulder

Casey Cobb University of Connecticut

Arnold Danzig Arizona State University

Antonia Darder University of Illinois, UrbanaChampaign

Linda Darling-Hammond Stanford University

Chad d'Entremont Strategies for Children

John Diamond Harvard University

Tara Donahue Learning Point Associates

Sherman Dorn University of South Florida

Christopher Joseph Frey Bowling Green State University

Melissa Lynn Freeman* Adams State College

Amy Garrett Dikkers University of Minnesota

Gene V Glass Arizona State University

Ronald Glass University of California, Santa Cruz

Harvey Goldstein Bristol University

Jacob P. K. Gross Indiana University

Eric M. Haas WestEd

Kimberly Joy Howard* University of Southern California

Aimee Howley Ohio University

Craig Howley Ohio University

Steve Klees University of Maryland

Jaekyung Lee SUNY Buffalo
Christopher Lubienski University of Illinois, UrbanaChampaign

Sarah Lubienski University of Illinois, UrbanaChampaign

Samuel R. Lucas University of California, Berkeley

Maria Martinez-Coslo University of Texas, Arlington

William Mathis University of Colorado, Boulder

Tristan McCowan Institute of Education, London

Heinrich Mintrop University of California, Berkeley

Michele S. Moses University of Colorado, Boulder

Julianne Moss University of Melbourne

Sharon Nichols University of Texas, San Antonio

Noga O'Connor University of Iowa

João Paraskveva University of Massachusetts, Dartmouth

Laurence Parker University of Illinois, UrbanaChampaign

Susan L. Robertson Bristol University

John Rogers University of California, Los Angeles

A. G. Rud Purdue University

Felicia C. Sanders The Pennsylvania State University

Janelle Scott University of California, Berkeley

Kimberly Scott Arizona State University

Dorothy Shipps Baruch College/CUNY

Maria Teresa Tatto Michigan State University

Larisa Warhol University of Connecticut

Cally Waite Social Science Research Council

John Weathers University of Colorado, Colorado Springs

Kevin Welner University of Colorado, Boulder

Ed Wiley University of Colorado, Boulder

Terrence G. Wiley Arizona State University

John Willinsky Stanford University

Kyo Yamashiro University of California, Los Angeles

* Members of the New Scholars Board 


\section{archivos analíticos de políticas educativas consejo editorial}

Editor: Gustavo E. Fischman (Arizona State University)

Editores. Asociados Alejandro Canales (UNAM) y Jesús Romero Morante (Universidad de Cantabria)

Armando Alcántara Santuario Instituto de Investigaciones sobre la Universidad y la Educación, UNAM México

Claudio Almonacid Universidad Metropolitana de Ciencias de la Educación, Chile

Pilar Arnaiz Sánchez Universidad de Murcia, España

Xavier Besalú Costa Universitat de Girona, España

Jose Joaquin Brunner Universidad Diego Portales, Chile

Damián Canales Sánchez Instituto Nacional para la Evaluación de la Educación, México

María Caridad García Universidad Católica del Norte, Chile

Raimundo Cuesta Fernández IES Fray Luis de León, España

Marco Antonio Delgado Fuentes Universidad Iberoamericana, México

Inés Dussel FLACSO, Argentina

Rafael Feito Alonso Universidad Complutense de Madrid, España

Pedro Flores Crespo Universidad Iberoamericana, México

Verónica García Martínez Universidad Juárez Autónoma de Tabasco, México

Francisco F. García Pérez Universidad de Sevilla, España

Edna Luna Serrano Universidad Autónoma de Baja California, México

Alma Maldonado Departamento de Investigaciones Educativas, Centro de Investigación y de Estudios Avanzados, México

Alejandro Márquez Jiménez Instituto de Investigaciones sobre la Universidad y la Educación, UNAM México

José Felipe Martínez Fernández University of California Los Angeles, USA
Fanni Muñoz Pontificia Universidad Católica de Perú

Imanol Ordorika Instituto de Investigaciones Economicas - UNAM, México

Maria Cristina Parra Sandoval Universidad de Zulia, Venezuela

Miguel A. Pereyra Universidad de Granada, España

Monica Pini Universidad Nacional de San Martín, Argentina

Paula Razquin UNESCO, Francia

Ignacio Rivas Flores Universidad de Málaga, España

Daniel Schugurensky Arizona State University

Orlando Pulido Chaves Universidad Pedagógica Nacional, Colombia

José Gregorio Rodríguez Universidad Nacional de Colombia

Miriam Rodríguez Vargas Universidad Autónoma de Tamaulipas, México

Mario Rueda Beltrán Instituto de Investigaciones sobre la Universidad y la Educación, UNAM México

José Luis San Fabián Maroto Universidad de Oviedo, España

Yengny Marisol Silva Laya Universidad Iberoamericana, México

Aida Terrón Bañuelos Universidad de Oviedo, España

Jurjo Torres Santomé Universidad de la Coruña, España

Antoni Verger Planells University of Amsterdam, Holanda

Mario Yapu Universidad Para la Investigación Estratégica, Bolivia 


\section{arquivos analíticos de políticas educativas conselho editorial}

Editor: Gustavo E. Fischman (Arizona State University) Editores Associados: Rosa Maria Bueno Fisher e Luis A. Gandin

(Universidade Federal do Rio Grande do Sul)

Dalila Andrade de Oliveira Universidade Federal de Minas Gerais, Brasil

Paulo Carrano Universidade Federal Fluminense, Brasil

Alicia Maria Catalano de Bonamino Pontificia Universidade Católica-Rio, Brasil

Fabiana de Amorim Marcello Universidade Luterana do Brasil, Canoas, Brasil

Alexandre Fernandez Vaz Universidade Federal de Santa Catarina, Brasil

Gaudêncio Frigotto Universidade do Estado do Rio de Janeiro, Brasil

Alfredo M Gomes Universidade Federal de Pernambuco, Brasil

Petronilha Beatriz Gonçalves e Silva Universidade Federal de São Carlos, Brasil

Nadja Herman Pontificia Universidade Católica -Rio Grande do Sul, Brasil

José Machado Pais Instituto de Ciências Sociais da Universidade de Lisboa, Portugal

Wenceslao Machado de Oliveira Jr. Universidade Estadual de Campinas, Brasil
Jefferson Mainardes Universidade Estadual de Ponta Grossa, Brasil

Luciano Mendes de Faria Filho Universidade Federal de Minas Gerais, Brasil

Lia Raquel Moreira Oliveira Universidade do Minho, Portugal

Belmira Oliveira Bueno Universidade de São Paulo, Brasil

António Teodoro Universidade Lusófona, Portugal

Pia L. Wong California State University Sacramento, U.S.A

Sandra Regina Sales Universidade Federal Rural do Rio de Janeiro, Brasil

Elba Siqueira Sá Barreto_Fundação Carlos Chagas, Brasil

Manuela Terrasêca Universidade do Porto, Portugal

Robert Verhine Universidade Federal da Bahia, Brasil

Antônio A. S. Zuin Universidade Federal de São Carlos, Brasil 